\title{
PERKAWINAN ANAK DALAM PERSPEKTIF HAK ASASI MANUSIA ${ }^{1}$
}

\author{
Oleh: \\ Dina Tsalist Wildana \\ Dosen Fakultas Hukum Universitas Jember \\ dinawildana@unej.ac.id \\ Irham Bashori Hasba \\ Dosen Fakultas Syariah UIN Maulana Malik Ibrahim Malang \\ irbash@syariah.uin-malang.ac.id
}

\begin{abstract}
Abstrak
Perkawinan di usia anak masih marak terjadi di beberapa wilayah. Tidak hanya di Indonesia, di beberapa wilayah masih tinggi angka perkawinan dini.Di Indonesia telah memiliki regulasi tentang perlindungan anak. Namun disisi lain perkawinan di usia anak masih tinggi bahkan menduduki peringkat ke 2 se Asia Tenggara setelah Kamboja. Hal ini jelas menunjukkan regulasi yang dimiliki tidak berjalan optimal. Pada tulisan ini akan membahas tentang beberapa hak anak yang dilanggar dengan adanya perkawinan dini. Kendati menunjukkan beberapa dampak negatifdari perkawinan di usia anak namun di akhir tulisan ini menawarkan beberapa formulasi agar perkawinan di usia anak tidak begitu banyak menyita hak-hak anak.
\end{abstract}

\section{Abstract}

Marriage at the age of children still occur in some areas. Not only in Indonesia, in some areas is still high number of early marriages. Indonesia has had a regulation on the protection of children. But on the other hand the marriage at the age of children is still high even ranked second in Southeast Asia after Cambodia. This obviously shows that regulation owned does not run optimally. This article will discuss about some children's rights that are violated by the existence of early marriage. Despite showing some of the negative effects of marriage on the age of the child but at the end of this writing offers several formulations so that children in the age of marriage is not so much seized the rights of the child.

\section{PENDAHULUAN; FENOMENA PENGABAIAN HAK ANAK}

Anak merupakan sebuah tahapan prosesperkembangan manusia yang dimulai sejak dalam kandungan hingga berusia 18 tahun. Pada usia tersebut, anak masih memiliki jiwa dan fisik yang belum stabil, belum dewasa, sehingga harus mendapatkan perlindungan. Jiwa yang belum dewasa kerap mendapatkan perlakukan yang kurang

${ }^{1}$ Tulisan ini pernah dipresentasikan pada Konfrensi Hak Asasi Manusia Tahun 2017 dengan tema "Hak Asasi Manusia dan Keadilan Eko - Sosial" yang dilaksanakan oleh SEPAHAM (Serikat Pengajar HAM) di Fakultas Hukum Universitas Tadulako Palu pada 1 - 3 Maret 2017 
tepat di berbagai negara.Banyak hal mengancam generasi anak-anak mulai dari narkotika, pornografi, kekerasan fisik, psikis dan seksual. Sementara disisi lain, hak asasi anak belum sepenuhnya diterima seperti hak atas kesehatan, pendidikan, dan perkembangan pertumbuhannya. Diantara hak-hak anak tersebut terdapat suatu kondisi yang menyebabkan hak-hak anak yang lain menjadi terhambat. Kondisi ini adalah perkawinan di usia anak. Pada penelitian ini akan fokus pada masalah perkawinan anak dengan alasan perkawinan anak menjadi penyebab terabaikannya berbagai macam hak anak.

Penelitian di kawasan Asia Afrika menunjukkan bahwa perkawinan anak disebabkan oleh ideologi patriarkhi, norma yang diskiminatif gender,rendahnya pendidikan dan faktor ekonomi. ${ }^{2}$ Indonesia menduduki peringkat ke dua di Asia Tenggara setelah Kamboja dalam hal angka perkawinan anak. ${ }^{3}$ Perkawinan anak adalah perkawinan yang dilakukan oleh orang yang masih berusia anak yaitu belum genap berusia 18 tahun baik laki-laki maupun perempuan. Perkawinan anak disebut-sebut sebagai penghambat pembangunan karena pada masa tersebut anak harus mengoptimalkan potensinya melalui pendidikan untuk selanjutnya dapat mengisi pembangunan.

Perkawinan anak selalu menyisakan dampak kurang menguntungkan terutama bagi perempuan. Perempuan sebagai pelaku perkawinan anak akan mengalami kerentanan berlipat dibanding laki-laki ${ }^{4}$. Hal ini disebabkan karena perempuan harus mengalami hubungan seksual yang terlalu dini, disusul kemudian dengan kehamilan dan persalinan dini pula. Dampak pada sisi kesehatan seperti masalah reproduksi, gizi buruk, dan kesehatan mental bagi ibu yang terlalu muda maupun anak yang dilahirkannya. Sementara gangguan kesehatan mental yang dikaji di kawasan Ethiopia,

${ }^{2}$ Joar Svanemyr et al, "Research priorities on ending child marriage and supporting married girls" (2015) 12:1 Reprod Health 80 at 2.

${ }^{3}$ Kompas Cyber Media, "Indonesia Urutan Kedua Tertinggi Pernikahan Remaja - Kompas.com", online:

<http://health.kompas.com/read/2015/12/13/110000623/Indonesia.Urutan.Kedua.Tertinggi.Pernikahan.Re maja $>$.

${ }^{4}$ Perempuan mengalami tingkat kerentanan yang lebih tingga dalam kasus perkawinan dini. seperti eksploitasi seksual, komersial bahkan diperdagangankan Lihat, Dewi Candraningrum, Anita Dhewy \& Andi Misbahul Pratiwi, "Takut akan Zina, Pendidikan Rendah dan Kemiskinan: Status Anak Perempuan dalam Pernikahan Anak di Sukabumi Jawa barat" (2016) 21:1 J Peremp, online: <http://www.jurnalperempuan.org/uploads/1/2/2/0/12201443/jp_88-riset-

takut_akan_zina_pendidikan_rendah_dan_kemiskinan_status_anak_perempuan_dalam_pernikahan_ana k_di_sukabumi_jawa_barat_.pdf $>$ at 152 . 
Afganistan dan Kurdistan Irak menunjukkan adanya hubungan antara perkawinan anak dengan angka bunuh diri. ${ }^{5}$

Melihat pola perkawinan anak, sesuai dengan laporan penelitian yang dilakukan Badan Pusat Statistik (BPS)dan UNICEF,memberikan gambaran bahwa di Indonesia khususnya wilayah pedesaan tingkat perkawinan anak lebih besar dari pada di wilayah perkotaan. ${ }^{6}$ Indikator perbedaan perspektif menikahkan anak di wilayah desa dan kota tersebut muncul karena ada asumsi yang menyatakan bahwa pendidikan dapat menjadi faktor yang dapat menunda perkawinan. Wajar jika di wilayah perkotaan tingkat pernikahan anak sedikit karena masyarakat kota lebih memprioritaskan pendidikan anaknya.

Perkawinan anak tidak dapat dipandang sebelah mata.Terdapat sejarah panjang yang menjadi akar permasalahannya. Budaya patriarkhi yang berkembang di beberapa negara menyebabkan ketidaksetaraan gender dan memposisikan perempuan sebagai beban. Ketidak setaraan gender berakibat pada rendahnya pendidikan, kesehatan dan semakin memperkuat budaya patriarkhi yang tidak berprinsip keadilan gender. ${ }^{7}$ Pada kondisi ini, perkawinan juga dianggap sebagai cara untuk meringankan beban orang tua. Beberapa masyarakat percaya bahwa laki-laki yang mengawini perempuan diusia anak merupakan suatu cara untuk memastikan keperawanan seorang perempuan. ${ }^{8}$

Lebih lanjut BPS dan UNICEF juga memperoleh data yang menyebutkan bahwa terdapat beberapa wilayah di Indonesia yang catatan tentang perkawinan anaknya sangat tinggi, seperti di Sulawesi Tengah, Sulawesi Barat, Kalimantan Tengah, dan Kalimantan Selatan. ${ }^{9}$ Kasus perkawinan dini juga terjadi di Pulau Jawa. Provinsi Jawa Timur juga memiliki angka yang tinggi terkait perkawinan dini.Perkawinan anak juga muncul

${ }^{5}$ Svanemyr et al, supra note 1 at 2.

6"Pernikahan Usia Anak Masih Marak di Indonesia", online: CNN Indones <http://www.cnnindonesia.com/gaya-hidup/20160723074431-277-146515/pernikahan-usia-anakmasih-marak-di-indonesia/>.

${ }^{7}$ Di India, budaya patriarkhi dipegang oleh mayoritas masyarakat khususnya di daerah pedesaan. Menurut Penelitian, pengaruh patriarkhi di daerah perkotaan tidak sebesar yang terjadi dipedesaan. Hal ini disebabkan karena perempuan di daerah perkotaan cukup mengenyam pendidikan.sehingga, memperbesar kesempatan kerja yang lebih baik daripada sebagai pekerja kasar yang dialami oleh perempuan pedesaan. Pendidikan yang baik juga memperbesar akses perempuan perkotaan terhadap kesehatan (penggunaan kontrasepsi) serta mengurangi "syndrome anak" Lihat Rashmi Sharma \& S Mukherjee, "Comparative study of selected parameters of gender discrimination in rural versus urban population of Ahmedabad, Gujarat" (2011) 2 Natl J Community Med 111 at 113-114.

8"WHO | Child marriages: 39000 every day", online: WHO<http://www.who.int/mediacentre/news/releases/2013/child_marriage_20130307/en/>.

${ }^{9}$ Media, supra note 2. 
disebabkan karena adanya konstruksi budaya, ekonomi, pendidikan, perjodohan orang tua, adat. ${ }^{10}$ Kekhawatiran tidak mentaati adat dengan cara menolak lamaran dikhawatirkan akan mendapat karma "kuwalat” yaitu tidak laku dan menjadi perawan tua. $^{11}$

Telah banyak kajian yang menjelaskan rentannya angka perkawinan dini terhadap kesehatan, kesejahteraan dan masalah sosial lainnya. Pernikahan dini yang banyak terjadi terhadap anak kebanyakan dilakukan karena tingkat pendidikan mereka rendah. ${ }^{12}$ Rekomendasi Badan Pusat Statistik (BPS) dan UNICEF untuk meminimalisir perkawinan dini berupa; Pertama, optimalisasi perlindungan anak melalui pendidikan. Kedua, memberikan pemahaman terkait norma sosial dan budaya kepada anak yang seharusnya dilakukan oleh guru, orang tua, tokoh agama, keluarga dekat, lingkungan dan masyarakat secara lebih umum. Ketiga,adanya akses bidang pendidikan yang berkualitas, mudah diakses dan biaya murah bagi anak khususnya anak perempuan. Keempat, kebijakan pemerintah tingkat pusat dan daerah harus lebih mengutamakan dan memperhatikan larangan terhadap perilaku perkawinan dini di masyarakat. Kelima,menguatkan program penelitian dan melakukan pendalaman penelitian yang khusus terkait perilaku pernikahan dini kepada anak. ${ }^{13}$

Beberapa daerah pedesaan di wilayah Kabupaten Jember terus mengalami lonjakan angka perkawinan dini. ${ }^{14}$ Uniknya masyarakat yang dominan melakukan hal tersebut adalah masyarakat Jember yang berasal dari Suku Madura. Factor pendorong perkawinan anak tidak jauh berbeda dengan motif yang terjadi di beberapa negara lain yaitu berkisar antara faktor kemiskinan, pendidikan, budaya, danpergaulan bebas. ${ }^{15}$

\section{PERKAWINAN ANAK DAN HAK ASASI MANUSIA}

\footnotetext{
${ }^{10}$ Siti Fatimah \& others, "Faktor-Faktor Pendorong Pernikahan Dini dan Dampaknya di Desa Mahak Baru Kecamatan Sungai Boh Kabupaten Malinau” (2016) 4:3 E-J Sosiatri-Sosiol at 203-204.

${ }^{11}$ Ibid at 204.

${ }^{12}$ Media, supra note 2.

${ }^{13}$ note 5 .

14“"Mengakhiri Perkawinan Anak Perempuan; Antara Konvenan Internasional dan Advokasi yang Belum Berakhir", online: <http://kajiangender.pps.ui.ac.id/wp-content/uploads/2016/04/Hari-2-sesi-1Maria-Ulfah-1.pdf $>$ at 3.

${ }^{15}$ Lihat Ibid.
} 
Perkawinan anak, khususnya bagi anak perempuan, merupakan tindakan yang dikategorikan merupakan tindakan melanggar hak kemanusiaan karenaperkawinan anak tersebut dapat menyebabkan pendidikan anak berakhir, tertutupnya kesempatan bagi perkembangan fisik anak, eksploitasi seksual melalui kehamilan dan melahirkan dini, dan meningkatkan resiko kekerasan seksual lainnya. ${ }^{16}$ Selain itu, akan membatasi akses perempuan di bidang ekonomi yang pada akhirnya akan berdampak pada posisi perempuan yang rentan terhadap kekerasan di dalam rumah tangga.

Pendidikan adalah hak setiap warga Negara tanpa mengacu pada umur dan jenis kelamin. Prioritas utama pendidikan diberikan kepada anak dan pemerintah berkewajiban menyediakan dan memenuhi hak anak atas pendidikan. ${ }^{17}$ Sementara kewajiban orang tua adalah mendukung dan menghindarkan berbagi hambatan yang dapat menganggu anak dalam menempuh pendidikan.

Beberapa Penelitian yang dilakukan di Bangladesh, Brunei, Chili, Ethiopia, Pakistan, Arab Saudi, India, Jordania, Indonesia dan beberapa negara lain, hambatan utama pendidikan bagi anak perempuan adalah perkawinan anak dan kehamilan. ${ }^{18} \mathrm{Hal}$ ini disebabkan karena setelah perkawinan, budaya menempatkan perempuan di dalam rumah tangga bahkan mencabut hak mereka atas pendidikan. ${ }^{19}$ Ironisnya terdapat kurang lebih $85 \%$ anak perempuan di Indonesia yang mengakhiri masa pendidikan mereka karena factor menikah. ${ }^{20}$

Bagi masyarakat Jember, masih terdapat steorip yang menyebut bahwa pendidikan bagi perempuan masih dianggap kurang memiliki manfaat. Masih banyak pendapat masyarakat yang menempatkan perempuan dengan tugas hanya pada sumur, dapur dan kasur yang tidak membutuhkan pendidikan di dalamnya.Kerap dijumpai perempuan baik secara sadar maupun dorongan orang tua tidak melanjutkan pendidikan. ${ }^{21}$ Padahal hilangnya kesempatan untuk menempuh pendidikan berbanding lurus dengan tertutupnya peluang untuk memperoleh pekerjaan dan penghasilan yang

\footnotetext{
${ }^{16}$ note 6.

${ }^{17}$ Katarina Tomasevski, Pendidikan Berbasis Hak Asasi Penyederhanaan Persyaratan Hak Asasi Manusia Global, Pelaporan Khusus Perserikatan Bangsa-Bangsa tentang Hak Atas Pendidikan dan biro Pendidikan Wilayah Asia Pasifik UNESCO (Bangkok) at 10.

${ }^{18}$ Ibid at 49.

${ }^{19}$ Ibid at 50.

${ }^{20}$ Kemajuan yangTertunda: Analisis Data Perkawinan Usia Anak di Indonesia (Jakarta: Badan Pusat Statistik (BPS) dan UNICEF, 2016) at 12.

${ }^{21}$ Hasil Observasi dan wawancara dengan masyarakat Dusun Tegalgusi Kecamatan Mayang Kabupaten Jember.
} 
layak bagi mereka. ${ }^{22}$ Akibatnya setelah perkawinan perempuan sangat tergantung sepenuhnya terhadap suaminya. Kalaupun ada yang bekerja maka perempuan menempati posisi sebagai pekerja kasar.

Pendidikan dan terbukanya peluang kerja terbukti mampu mengurangi praktik perkawinan anak. Malawi, salah satu negara termiskin di dunia yang juga memiliki angka tinggi terhadap perkawinan anak menganggap bahwa pendidikan dapat mendorong warganya untuk berkontribusi dalam perekonomian dan pembangunan. ${ }^{23}$

Selain berdampak pada terhambatnya pendidikan dan kesempatan untuk berkembang, perkawinan anak berdampak buruk pada kesehatan khususnya perempuan. Hal ini disebabkan karena perempuan mengalami kehamilan dan melahirkan di usia anak. Survei terhadap 16 juta anak perempuan yang melahirkan, terdapat 50 ribu kasus yang mengalami kematian. ${ }^{24}$ Bayi yang dilahirkan pun mengalami resiko tinggi atas kelahiran premature dan kurang gizi. Selain kesehatan fisik, perkawinan anak juga berpengaruh pada kesehatan psikis atau mental baik dalam taraf ringan, sedang, maupun berat. Gangguan tersebut berupa kecemasan, depresi bahkan berniat untuk bunuh diri. ${ }^{25}$ Tekanan mental ini disebabkan karena perempuan tidak memiliki status, kekuasaan, dukungan dan kontrol atas kehidupaan mereka sendiri.

Indonesia menempati rangkaning pertama diAsia Tenggara mengenai kematian ibu dan anak. Gangguan kesehatan perempuan diwilayah Jawa Barat mengalami peningkatan dalam 5 tahun terakhir. ${ }^{26}$ Menurut SDKI 2012, perempuan usia 15-19 tahun yang mengandung dan melahirkan cenderung mengalami komplikasi sehingga menyebabkan kematian ibu dan anak. ${ }^{27}$ Survey yang dilakukan di Jawa Barat menunjukkan bahwa perkawinan anak dilakukan oleh yang berlatar pendidikan SD sebesar 46,8\% disusul kemudian pendidikan SMP 33.9\% sedangkan SMA sebesar 5,8 $\%$. Pendidikan rendah menyebabkan perempuan rentan terhadap kekerasan dalam rumah tangga, terutama pihak yang tidak memiliki penghasilan.

Di Pakistan, tingginya perkawinan anak khususnya perempuan akan berdampak pada terabaikannya hak anak perempuan. Hak atas kesehatan terkait usia kesuburan

\footnotetext{
${ }^{22}$ Joar Svanemyr et al, "Preventing child marriages: first international day of the girl child 'my life, my right, end child marriage"” (2012) 9:1 Reprod Health 31 at 1.

${ }^{23}$ note 6 .

${ }^{24}$ Ibid.

${ }^{25}$ note 19 at 13 .

${ }^{26}$ Candraningrum, Dhewy \& Pratiwi, supra note 3 at 158.

${ }^{27}$ Ibid at 178.
} 
perempuan, sehingga perkawinan anak memicu kelahiran berulang, kehamilan yang tidak diinginkan, penghentian kehamilan. ${ }^{28}$ Sementara kehamilan di usia anak meningkatkan resiko komplikasi selama kehamilan dan persalinan.Sedangkan kondisi bayi yang dilahirkan dari ibu dibawah umur 18 berupa resiko bayi meninggal, terlahir premature, kurus dan mengalami masalah kesehatan yang serius. ${ }^{29}$

\section{SUDAHKAN PEMERINTAH INDONESIA MELINDUNGI HAK ANAK?}

Perlindungan terhadap anak merupakan amanah dari Konvensi Hak Anak (KHA) dimana Indonesia menjadi salah satu dari dari 192 negara yang meratifikasinya. ${ }^{30}$ Dalam hal hak asasi manusia, khususnya hak asasi anak, pemerintah wajib membuat instrumen baik berupa regulasi maupun petunjuk operasional terpenuhinya hak tersebut.

Amanah KHA yang telah diratifikasi oleh Indonesia dalam bentuk berbagai undang-undang mewajibkan pemenuhan anak untuk didengar, terbebas dari diskriminasi, terbebas dari kekerasan yang dapat mengganggu kesehatan, penghapusan eksploitasi yang dapat menghilangkan kesempatan anak atas kesehatan, tekanan fisik dan mental, pendidikan, maupun tekanan secara moral, spiritual, maupun sosialnya. Perlindungan hak anak yang menjadi wilayah kerja pemerintah adalah dengan cara penyediaan regulasi yang peduli terhadap anak.

Kondisi saat ini, negara masih ragu-ragu dalam menentukan batas usia anak. Meskipun konvensi tetang hak anak yang telah diamini oleh Indonesiayang menyebutkan sampai batas umur 18 tahun, akan tetapi regulasi lain masih dibiarkan ada meskipun batasan umur tidak sama. Undang-Undang Perkawinan misalnya, yang menyebut umur dalam beberapa kategori, yaitu boleh menikah dengan syarat mendapatkan ijin dari orang tua dengan ketentuan umur 19 tahun bagi laki-laki dan umur 16 tahun bagi perempuan. Berikutnya menikah tanpa syarat artinya tanpa memerlukan izin orang tua yaitu telah mencapai umur 21 tahun baik bagi laki-laki

\footnotetext{
${ }^{28}$ Sebagai upaya meminimalisir perkawinan anak, Pemerintah Pakistan mempromosikan hak-hak kesehatan khususnya bagi perempuan, mengingat reprosuksi seringkali menjadikan suami sebagai subjek (suami cenderung menginginkan banyak anak) sementara istri sebagai objek.Muazzam Nasrullah et al, "Girl Child Marriage and Its Effect on Fertility in Pakistan: Findings from Pakistan Demographic and Health Survey, 2006-2007" (2014) 18:3 Matern Child Health J 534.

${ }^{29}$ Svanemyr et al, supra note 20 at 1 .

${ }^{30}$ Indonesia meratifikasi Konvensi Hak Anak Melalui Keputusan Presiden Nomor 36 Tahun 1990 dengan diikuti lahirnya Undnag-Undnag tentang Perlindungan Anak.Tomasevski, supra note 16 at 6.
} 
maupun perempuan. ${ }^{31}$ Selain dua kategori tersebut ada konsep anak yaitu umur 18 tahun yang harus mendapat akses pendidikan. ${ }^{32}$

Menarik untuk dikaji bahwa pada kategori pertama, pemerintah menyadari usia tersebut belum cakap/belum dewasa bagi laki-laki maupun perempuan sehingga dibutuhkan ijin dari orang tua. ${ }^{33}$ Alasan ini diperkuat dengan penyebutan anak pada usia sebelum 18 tahun sehingga pada usia tersebut anak masih dalam pengawasan orang tuanya. Nilai lebih dari Undang-Undang No. 1 Tahun 1974Tentang Perkawinan adalah adanya penentuan batasan umur anak yaitu 18 tahun.Meskipun kelemahannya konsep ini belum dioperasionalkan dalam bentuk kebijakan. Sofia Hardani menyebutkan bahwa pada regulasi tentang perkawinan pada dasarnya telah mengandung perlindungan anak melalui konsep "kedewasaan" yaitu menyebutkan batas umur 18 tahun untuk perempuan dan 21 untuk laki-laki untuk melakukan perkawinan. ${ }^{34}$ Akan tetapi konsep ini tidak dipahami oleh masyarakat maupun penegak hukum perkawinan.Mengenai batas minimum kawin dianggap tidak lagi relevan untuk saat ini sehingga perlu segera dilakukan pembaharuan. ${ }^{35}$

Akan tetapi harapan yang pernah diupayakan sekelompok masyarakat berupa pengajuan revisi batas minimum perkawinan ditolak oleh Mahkamah Konstitusi dengan alasan agama dan budaya. ${ }^{36}$ Keadaan ini menunjukkan bahwa pemerintah Indonesia menutup mata atas temuan penelitian tentang dampak negatif perkawinan di usia dini bagi anak. Dengan kata lain, negara mengabaikan hak dasar anak khususnya anak perempuan dengan cara membiarkan terjalannya hukum yang tidak melindungi

\footnotetext{
${ }^{31}$ Lihat Pasal 6 (2) dan bandingan dengan Pasal 7 (1) Undang-Undang Republik Indonesia Nomor 1 Tahun 1974 Tentang Perkawinan].

${ }^{32}$ Lihat tentang bab hak dan kewajiban orang tua dan anak Pasal 47 (1) Ibid.

${ }^{33}$ Dalam Islam terdapat dua pendapat tentang izin perkawinan, yaitu pendapat Ibnu Qayyim izin dari para pihak yang akan kawin dan pendapat Asy-Syafi'I izin dari wali bersifat mutlak. Yang membedakan dari kedua pendapat ini adalah pada pendapat pertama apabila para pihak telah dewasa dan para mempelai sepakat untuk kawin maka tidak perlu menunggu persetujuan orang tua.Sedangkan pendapat kedua menjelaskan bahwa posisi orang tua sangat urgen sehingga berhak untuk memaksa atau melarang perkawinan anak perempuannya. Undang-Undang perkawinan tampaknya menggunakan mengakomodir dua pendapat tersebut dimana izin orang tua pada suatu kondisi tertentu dibutuhan dan tidak diperlukan pada kondisi yang lain yaitu telah berumur 21 tahun. Arman Suriyono, Persetujuan Orang Tua dalam Pernikahan (Studi Komparasi Atas Pandangan Asy-Syafi'dan Ibnu Qayyim alJawziyyah) Universitas Islam Negeri Sunan Kalijaga, 2010) [unpublished] at 1.

${ }^{34}$ Sofia Hardani, "Analisis tentang Batas Umur untuk Melangsungkan Perkawinan Menurut Undang-Undang Perkawinan di Indonesia” (2016) 40:2 ANIDA’126 at 130.

${ }^{35}$ Ahmad Masfuful Fuad, "Menelaah Kembali Ketentuan Usia Minimal Kawin di Indonesia melalui Perspektif Hermeneutika" (2015) 11:2 Al-Maslahah J Ilmu Syariah, online: <http://jurnaliainpontianak.or.id/index.php/Almaslahah/article/view/145> at 21.

${ }^{36}$ Risalah Sidang Mahkamah Konstitusi Republik Indonesia perihal Pengujian Undang-Undang Nomor 1 Tahun 1974 tentang Perkawinan
} 
anak.Perkawinan sebelum usia 18 tahun disebut sebagai perkawinan anak merupakan pelanggaran terhadap hak asasi manusia. ${ }^{37}$

Undang-undang perlindungan anak yang merupakan turunan dari konvensi hak anak jelas menyebutkan anak sejak di dalam kandungan hingga berumur 18 tahun. ${ }^{38}$ Ketentuan ini sama dengan batas umur anak dalam undang-undang kesehatan dengan mewajibkan negara menjamin hak atas kesehatan. ${ }^{39}$ Sampai umur tersebut, baik orang tua atau pemerintahdan negara wajib memastikan hak-hak anak terpenuhi sehingga dapat hidup, tumbuh dan berkembang dengan normal. Salah satu bentuk perlindungan terhadap anak yang harus dilakukan orang tua adalah mencegah perkawinan di usia dini terhadap anak.

Dari uraian diatas tampak bahwa pemerintah masih inkonsisten dalam menentukan batas usia anak. Hal ini tidak berdampak baik pada proses perlindungan anak. Pada satu kondisi seseorang di lindungi karena masih berstatus anak, namun disaat yang bersamaan dia akan diperlakukan sebagai orang dewasa dimana pemerintah tidak lagi berkewajiban memberikan perlindungan.

\section{KESIMPULAN}

Hampir setiap negara mengalami masalah yang sama yaitu perkawinan anak. Penyebabnya pun tidak jauh berbeda.Negara Malawi menerapkan beberapa kebijakan yang bersifat prefentif sebagai upaya pencegahan dan persuatif sebagai upaya optimalisasi kondisi yang terlanjur terjadi. Upaya prefentif tersebut adalah menyediakan pendidikan gratis, mengerahkan beberapa komponen masyarakat untuk mengarahkan pendidikan bagi perempuan, membuat regulasi dengan cara menunaikan batas minimum perkawinan yaitu 18 tahun. $^{40}$ Sedangkan terhadap perkawinan anak yang telah berlangsung, pemerintah membuat kebijakan berupa terbukanya kembali kesempatan pendidikan bagi perempuan pasca melahirkan, memperluas akses kesehatan reproduksi bagi pasangan muda. ${ }^{41}$ Kebijakan yang hampir sama dilakukan oleh Mozambik yaitu

\footnotetext{
${ }^{37}$ Pasal 16 (2) Universal Declaration of Human Rights

${ }^{38}$ Indonesia, supra note 41, v Pasal 1 (1).

${ }^{39}$ Undang-undang Republik Indonesia nomor 36 tahun 2009 tentang Kesehatan, Republik Indonesia, 2009 [Undang-undang Republik Indonesia nomor 36 tahun 2009 tentang Kesehatan] at Pasal

${ }^{40}$ note 6.

${ }^{41}$ Ibid.
} 131. 
komunikasi dan kampanye terhadap masyarakat untuk pencegahan perkawinan anak, peningkatan pendidikan khusunya bagi perempuan. Selain itu juga memperluas pendidikan seks dan keluarga berencana, mendukung kehidupan anak perempuan sudah menikah, dan reformasi hukum. ${ }^{42}$

Perkawinan anak, baik laki-laki maupun perempuan cenderung menyerang hak asasi perempuan. Adapun hak anak yang terabaikan adalah hak atas pendidikan, hak untuk tumbuhdan berkembang dan kesehatan.Tidak banyak yang meneliti dan mengkaji dampak perkawinan anak bagi laki-laki.Sebaliknya, peneliti lebih memperhatikan perempuan sebagai pelaku perkawinan anak.

Berkaca dari upaya negara lain dalam hal perkawinan anak dan upaya memberikan perlindungan terhadap anak, Indonesia masih mengalami ketertinggalan, khususnya mengenai batas minimum perkawinan sebagai upaya mengakhiri perkawinan anak dan pemenuhan hak anak khusunya perempuan.

\section{REFERENSI}

Undang-Undang Republik Indonesia Nomor 1 Tahun 1974 Tentang Perkawinan, Indonesia [Undang-Undang Republik Indonesia Nomor 1 Tahun 1974 Tentang Perkawinan].

Undang-Undang Republik Indonesia Nomor 22 Tahun 2009 tentang Lalu Lintas dan Angkutan Jalan, Pemerintah Republik Indonesia, 2009 [Undang-Undang Republik Indonesia Nomor 22 Tahun 2009 tentang Lalu Lintas dan Angkutan Jalan].

Undang-undang Republik Indonesia nomor 36 tahun 2009 tentang Kesehatan, Republik Indonesia, 2009 [Undang-undang Republik Indonesia nomor 36 tahun 2009 tentang Kesehatan].

Indonesia, Republik. Undang-undang Republik Indonesia Nomor 23 Tahun 2002 Tentang Perlindungan Anak (Kementerian Pemberdayaan Perempuan, Republik Indonesia, 2002).

Saputra, Anjar Kurniawan \& Zulkifli Djunaidi. Persepsi Anak di Bawah Umur Terhadap Keselamatan Berkendara Sepeda Motor di Perumahan Munjul (Studi Kasus RT 11 RW 05 Kelurahan Munjul Jakarta Utara Tahun 2014) Universitas Indonesia, 2014) [unpublished].

42، $\mathrm{PMNCH}$ | Press release: Mozambique launches national strategy to end child marriage", online: $W H O<$ http://www.who.int/pmnch/media/news/2016/mozambique/en/>. 
Suriyono, Arman. Persetujuan Orang Tua dalam Pernikahan (Studi Komparasi Atas Pandangan Asy-Syafi'dan Ibnu Qayyim al-Jawziyyah) Universitas Islam Negeri Sunan Kalijaga, 2010) [unpublished].

Anshor, Maria Ulfah. "Mengakhiri Perkawinan Anak Perempuan; Antara Konvenan Internasional dan Advokasi yang Belum Berakhir", online: $<$ http://kajiangender.pps.ui.ac.id/wp-content/uploads/2016/04/Hari-2-sesi-1Maria-Ulfah-1.pdf>.

Candraningrum, Dewi, Anita Dhewy \& Andi Misbahul Pratiwi. "Takut akan Zina, Pendidikan Rendah dan Kemiskinan: Status Anak Perempuan dalam Pernikahan Anak di Sukabumi Jawa barat" (2016) 21:1 J Peremp, online: <http://www.jurnalperempuan.org/uploads/1/2/2/0/12201443/jp_88-risettakut_akan_zina_pendidikan_rendah_dan_kemiskinan_status_anak_perempuan _dalam_pernikahan_anak_di_sukabumi_jawa_barat_.pdf >.

Fatima, Fatima. "Perempuan Sebagai Anak dan Hak-Haknya dalam Perkawinan (Studi terhadap Peraturan Perundang-undangan dan Praktek di Pengadilan Agama)" (2012) 2:1 Junal Indo-Islam 125.

Fatimah, Siti \& others. "Faktor-Faktor Pendorong Pernikahan Dini dan Dampaknya di Desa Mahak Baru Kecamatan Sungai Boh Kabupaten Malinau” (2016) 4:3 E-J Sosiatri-Sosiol.

Fuad, Ahmad Masfuful. "Menelaah Kembali Ketentuan Usia Minimal Kawin di Indonesia melalui Perspektif Hermeneutika" (2015) 11:2 Al-Maslahah J Ilmu Syariah, online: <http://jurnaliainpontianak.or.id/index.php/Almaslahah/article/view/145>.

Hardani, Sofia. "Analisis tentang Batas Umur untuk Melangsungkan Perkawinan Menurut Undang-Undang Perkawinan di Indonesia” (2016) 40:2 ANIDA' 126.

Nasrullah, Muazzam et al. "Girl Child Marriage and Its Effect on Fertility in Pakistan: Findings from Pakistan Demographic and Health Survey, 2006-2007” (2014) 18:3 Matern Child Health J 534.

Sharma, Rashmi \& S Mukherjee. "Comparative study of selected parameters of gender discrimination in rural versus urban population of Ahmedabad, Gujarat" (2011) 2 Natl J Community Med 111.

Svanemyr, Joar et al. "Preventing child marriages: first international day of the girl child 'my life, my right, end child marriage'”' (2012) 9:1 Reprod Health 31.

"Research priorities on ending child marriage and supporting married girls" (2015) 12:1 Reprod Health 80.

Media, Kompas Cyber. "Indonesia Urutan Kedua Tertinggi Pernikahan Remaja Kompas.com", online: 
<http://health.kompas.com/read/2015/12/13/110000623/Indonesia.Urutan.Kedua .Tertinggi.Pernikahan.Remaja>.

Tomasevski, Katarina. Pendidikan Berbasis Hak Asasi Penyederhanaan Persyaratan Hak Asasi Manusia Global, Pelaporan Khusus Perserikatan Bangsa-Bangsa tentang Hak Atas Pendidikan dan biro Pendidikan Wilayah Asia Pasifik UNESCO (Bangkok).

Kemajuan yangTertunda: Analisis Data Perkawinan Usia Anak di Indonesia (Jakarta: Badan Pusat Statistik (BPS) dan UNICEF, 2016).

"Pernikahan Usia Anak Masih Marak di Indonesia", online: CNN Indones $<$ http://www.cnnindonesia.com/gaya-hidup/20160723074431-277-

146515/pernikahan-usia-anak-masih-marak-di-indonesia/> .

"WHO | Child marriages: 39000 every day", online: WHO <http://www.who.int/mediacentre/news/releases/2013/child_marriage_20130307 len/>.

"MK tolak naikkan batas usia minimal untuk menikah", online: BBC Indones $<$ http://www.bbc.com/indonesia/berita_indonesia/2015/06/150618_indonesia_m k_nikah>.

"PMNCH | Press release: Mozambique launches national strategy to end child marriage", online:

WHO <http://www.who.int/pmnch/media/news/2016/mozambique/en/>. 